\title{
EPIDEMIOLOGY OF HUMAN VISCERAL LEISHMANIASIS IN TAOUNATE, A NORTHERN PROVINCE OF MOROCCO
}

\author{
GUESSOUS-IDRISSI N.*, HAMDANI A.*, RHALEM A.**, RIYAD M.*, \\ SAHIBI H.**, DEHBI F.***, BICHICHI M.*, ESSARI A.* \& BERRAG B.**
}

\begin{abstract}
Summary :
We report the preliminary results of an epidemiological survey carried out in the locality of Ouled Hcein, province of Taounate (North Morocco) around one visceral leishmaniasis infant case. The strain isolated from the child was characterized by three methods as Leishmania infantum and its isoenzyme pattern was indistinguishable from zymodeme MON-1. The human survey in the locality of origin of the index case did not show any additional case and the serology was negative for the whole people sampled. The canine survey showed that the highest seroprevalence of the canine disease was found in the locality of Ouled Hcein (27.1 \%) when compared to 4 surrounding localities. The entomological survey showed that amongst the demonstrated L. infantum vectors around the Mediterranean Basin, Phlebotomus longicuspis was the predominant species. Furthermore, the survey led to the indentification of one female of $P$. ariasi naturally infected with $L$. infantum, so this species should be at least one of the vectors of this parasite in this area. Thus, this study confirms that the transmision cycle of $L$. infantum in North Morocco is similar to the cycle found in the remaining Mediterranean area.
\end{abstract}

KEY WORDS : epidemiology, visceral leishmaniasis.
Résumé : ÉPIDÉmIOLOGIE DE LA LeISHMANIOSE VISCÉRALE hUMAINE DANS la PROVINCE DE TAOUNATE (NORD DU MAROC)

Les auteurs rapportent les résultats préliminaires d'une enquête épidémiologique autour d'un cas de leishmaniose viscérale infantile de la localité de Ouled Hcein, province de Taounate (Nord du Maroc). La souche isolée à partir de l'enfant a été identifiée par trois méthodes comme Leishmania infantum et l'analyse isoenzymatique montre une similitude totale avec le zymodème MON-1. Au cours de l'enquête humaine menée dans la localité d'origine du cas index, aucun autre cas n'a été diagnostiqué, et la sérologie s'est avérée négative pour toutes les personnes testées. L'enquête canine menée dans cette même localité et dans quatre autres voisines a montré que la plus forte séroprévalence $(27,1 \%$ ) était retrouvée dans celle du cas index. L'enquête entomologique a montré que Phlebotomus longicuspis est l'espèce prédominante parmi celles déjà démontrées comme vecteur de L. infantum autour de la Méditerranée. Par ailleurs, l'identification d'une femelle de P. ariasi naturellement infestée par L. infantum suggère que cette espèce est au moins l'un des vecteurs du parasite. Cette étude confirme donc que le cycle de transmission de L. infantum dans le Nord du Maroc est similaire à celvi du reste du Bassin Méditerranéen.

MOTS CLÉS : épidémiologie, leishmaniose viscérale.

\section{INTRODUCTION}

\section{T} he South of the Mediterranean Basin is one of the endemic foci of visceral leishmaniasis due to Leishmania infantum. The dog (Canis canis) is the main reservoir of the parasite (Dedet, $1994 a$ ), while sandflies of the subgenous Larroussius are the incriminated vectors (Killick-Kendrick, 1990). In Morocco, visceral leishmaniasis is primarily located in the North with some 50 pediatric cases notified each

\footnotetext{
* Unité d'Études et de Recherche sur les Leishmanioses, Laboratoire de Parasitologie-Mycologie, Faculté de Médecine et Pharmacie et Centre Hospitalier Ibn Rochd, 19, rue Tarik Ibn Ziad, BP 9154, Casablanca, Maroc

** Département de Parasitologie, Institut Agronomique et Vétérinaire Hassan II, Rabat, Maroc.

*** Service de Pédiatrie II, Hôpital d'Enfants, Casablanca, Maroc. Correspondence: Pr. Nouzha Guessous-Idrissi.

Tel: 212-2-271630/222555, Poste/Ext: 305 - Fax: 212-2-475560

- E. mail: nguessous@casanet. net. ma.
}

year to the Ministry of Health (Ministère de la Santé Publique du Maroc, 1992). However, very small number of sporadic cases were reported in the South. The province of Taounate (North Morocco) is known as a hypoendemic focus of human visceral leishmaniasis according to the Ministry of Health data. However, never before had a survey been carried out to specify the parasite, vector and reservoir within this focus. Around one visceral leishmaniasis infant case, a three-fold epidemiological survey was carried out: i) a human survey including clinical and serological examination; $i$ i) a canine survey to assess/confirm the role of dog as reservoir of the disease; iii) an entomological survey looking for the vector in this area.

\section{MATERIAL AND METHODS}

I

$\mathrm{n}$ august 1994, a two-year old male born in the locality of Ouled Hcein (Province of Taounate) was hospitalized at the Pediatric Hospital of Casa- 
blanca for typical signs of visceral leishmaniasis. No history of travel outside of the province since birth was reported, so this was clearly established as a native case.

In this patient direct examination of bone marrow by Giemsa staining showed a great number of amastigotes. The culture was positive on NNN medium and the serology by IFAT using $L$. infantum antigen reached a titre of 1:2560. The isolated strain was characterized by three methods: isoenzyme electrophoresis on cellulose acetate using 10 enzymes (NHi, NHd, SOD, GPI, GOT, MDH, G6PD, 6PGD, ME, PGM); immunofluorescence using monoclonal antibodies (MAbs 2E5-A8 specific of $L$. donovani, 5B8-B3 specific of $L$. major, 1H2-A8 and 2B4-A11 specific of L. tropica); and excreted factors (EFs) using polyclonal sera against $L$. infantum (LRC-L47), L. donovani donovani (LRC-L52), and L. tropica (LRC-L36). In each case results were compared to WHO reference strains of $L$. infantum (MHOM/TN/80/IPT1), L. tropica (MHOM/SU/74/K27), and $L$. major (MHOM/SU/73/5ASKH).

With the approval of the local and national authorities and of the inhabitants of Ouled Hcein, a human survey was carried out in November 1994 among 81 people from 24 neighbouring families of the index case. Fourty four (44) of those studied were children (54\%) with a sex-ratio of 1 and a mean age of $7.28 \pm 0.6$ years (range: 2 months to 16 years). Data recorded at each household included the type of residence, the number and ages of all household members, a history of infant and childhood death or previous cases of visceral leishmaniasis, the type and number of animals kept with special emphasis on sick or dead dog. Clinical examination looking for splenomegaly and blood sampling were performed. Serology to look for antibodies to L. infantum was done by indirect immunofluorescence using the strain isolated from the index case. The canine serosurvey started in November 1994 and was carried out among all dogs of Ouled Hcein (70) and four surrounding localities: Bouhouda (58), Imaghdane (34), Hmirou (21) and Kalaa (20). Upon agreement of the owners, dogs were examined and blood sampled for indirect immunofluorescence and ELISA using a Moroccan strain of canine L. infantum, indistinguishable from zymodeme MON-1 on 10 enzymes. The entomological survey was carried out by monthly trapping throughout the 1995 transmission season (i.e. May to December) in the locality of Ouled Hcein. Aspiration and CDC light traps were used inside while sticky traps were used outside. The objective of this survey was the determination of the vector, so it was not extended to other surrounding localities.

\section{RESULTS}

1 he isolated Leishmania strain from the index case was characterized by the three methods as L. infantum: the promastigotes reacted with monoclonal antibody 2E5A8 and gave B2 EF serotype. Finally, the isoenzyme analysis confirmed L. infantum when compared to reference strains of $L$. infantum, L. major and L. tropica and the isoenzyme pattern on the 10 tested enzymes was indistinguishable from zymodeme MON-1.

The retrospective data obtained from the questionnaires and the human survey did not identify any suspicious cases either during this survey or in the past. The serology was negative for the whole sample. Furthermore, no history of sick or dead dog related to leishmaniasis was clearly estalished.

The canine survey showed that the highest seroprevalence $(27.1 \%)$ was recorded in the locality of Ouled Hcein (Table I) . Furthermore, 3 dogs exhibited some clinical signs of canine leishmaniasis mainly lymphadenopathy. Unfortunately the owners of these dogs did not allow their sampling for culture. The results of the entomological survey are summarized in table II. Sandflies appeared in June and 4,939 specimens were collected of which 3,501 were of Pblebotomus genus. The seasonality of the whole species of this genus show two picks, one in June related to P. sergenti and the second in August-September related to P. longicuspis (Fig. 1). Most collected sandflies were endophilic and mainly caught from houses and stables. In November 1995 one specimen of P. ariasi caught in the bedroom

\begin{tabular}{|c|c|c|c|c|}
\hline \multirow[b]{2}{*}{ Localities } & \multirow[b]{2}{*}{$\mathrm{Nb}$ of sera tested } & \multicolumn{2}{|c|}{$\mathrm{Nb}$ and $\%$ of dogs positive by: } & \multirow{2}{*}{$\begin{array}{c}\mathrm{Nb} \text { of dogs clinically } \\
\text { suspected }\end{array}$} \\
\hline & & IFAT & ELISA & \\
\hline Ouled Hcein & 70 & $15(21.4 \%)$ & $19(27.1 \%)$ & $3(4.2 \%)$ \\
\hline Bouhouda & 58 & $5(8.6 \%)$ & $7(12.1 \%)$ & $2(3.4 \%)$ \\
\hline Imaghdane & 34 & $0(0 \%)$ & $0(0 \%)$ & $0(0 \%)$ \\
\hline Hmirou & 21 & $3(14.2 \%)$ & $5(23.8 \%)$ & $0(0 \%)$ \\
\hline Kalaa & 20 & $2(10 \%)$ & $2(10 \%)$ & $0(0 \%)$ \\
\hline Total & 203 & $25(12.3 \%)$ & $33(16.3 \%)$ & $5(2.3 \%)$ \\
\hline
\end{tabular}

Table I. - The prevalence of canine leishmaniasis in Ouled Hcein and four surrounding localities using IFAT and ELISA. 


\begin{tabular}{|c|c|c|c|c|c|}
\hline Species & $\begin{array}{c}\text { Houses } \\
44 \%\end{array}$ & $\begin{array}{l}\text { Stables } \\
55 \%\end{array}$ & $\begin{array}{c}\text { Outside } \\
3.8 \%\end{array}$ & $\begin{array}{c}\text { Total } \\
\text { (Nb. females) }\end{array}$ & $\%$ \\
\hline$P$. sergenti & 802 & 734 & 0 & $1,536(419)$ & 43.9 \\
\hline P. longicuspis & 500 & 883 & 116 & $1,499(408)$ & 42.8 \\
\hline P. papatasi & 45 & 171 & 0 & $216(46)$ & 6.1 \\
\hline P. ariasi & 64 & 88 & 0 & $216(76)$ & 4.7 \\
\hline P. perniciosus & 29 & 51 & 7 & $87(42)$ & 2.5 \\
\hline Subtotal & 1,440 & 1,927 & 134 & 3,501 (991) & 100 \\
\hline S. minuta & 442 & 215 & 781 & 1,438 & \\
\hline Total & 1,882 & 2,142 & 915 & 4,939 & \\
\hline
\end{tabular}

Table II. - Collected sandflies in the locality of Ouled Hcein according to the site.

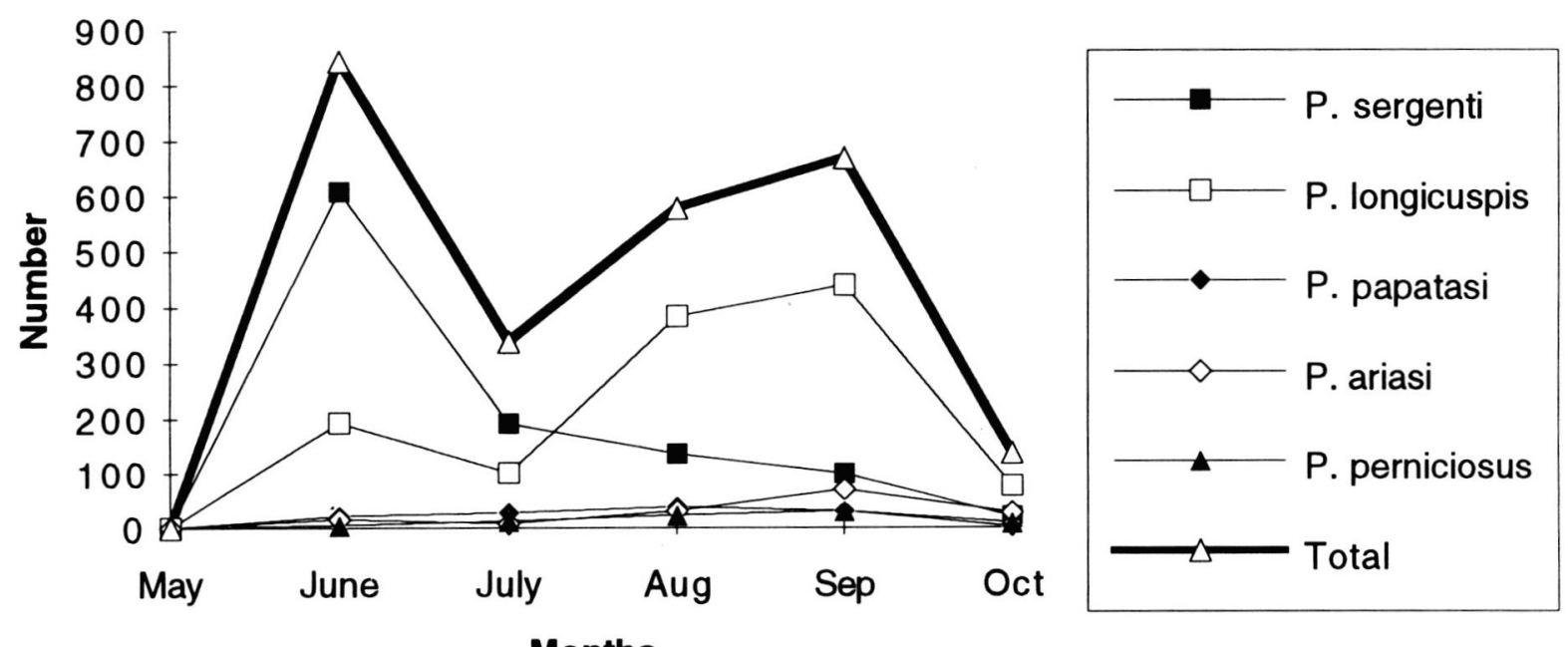

Fig. 1. - Seasonality of Phlebotomus species in Ouled Hcein.

of the index case was found naturally infected with promastigotes identified as L. infantum by monoclonal antibodies immunofluorescence (positive reaction with MAb 2E5A8); the culture did not allow the isolation of the parasite because of initial fungal contamination of the sandfly midgut.

\section{DISCUSSION}

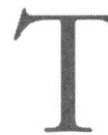

he province of Taounate is located in the preRif Mountains (North of Morocco) and has 619,000 inhabitants (1995 census). Ouled Hcein locality is at an altitude of $1,100 \mathrm{~m}$ and has subhumid climate (mean annual rainfall of $800 \mathrm{~mm}$ ). The soil is a mixture of schistose and clay, with plantations of olive and fig trees besides some wild specimens. In this locality, sheep and goats are raised. Finally, 887 people from 153 families constitute its whole population.

The province of Taounate is one of the oldest " risk areas " of visceral leishmaniasis in Morocco according to the data of the Ministry of Health (unpublished data): 21 cases were notified between 1991 and 1995 . This number is probably underestimated as physicians were not obliged to report leishmaniasis cases until January 1996. However it can probably be assumed that this province is a hypoendemic zone of human visceral leishmaniasis. The index visceral leishmaniasis case presented here was interesting because given his age and the absence of any travel history outside of his locality, he was a true autochtonous case. As in the remaining Mediterranean Basin (Dedet, 1994b) the characterization of the isolated parasite confirmed that pediatric visceral leishmaniasis in Taounate province is related to L. infantum MON-1. An active zoonotic transmission cycle of $L$. infantum in Ouled Hcein focus is suggested by the observed canine seroprevalence $(27.1 \%)$ which is much higher than reported from other Mediterranean areas like Spain: $8.9 \%$ (Martin Sanchez et al., 1994), France: $17 \%$ (Marty et al., 1992), Italy: $14.4 \%$ (Brandonisio et al., 1992) and Syria: 10\% (Dereure et al., 1991). It is well established that in most visceral leishmaniasis foci, the prevalence 
of the canine disease is much higher than in humans (Dedet, 1994a) so that the sporadic human cases reveal an active focus of canine leishmaniasis. In Ouled Hcein locality the parasite could not be isolated from the suspicious sick dogs for the reasons mentioned above. However, as previously reported the dog is definitely demonstrated as a reservoir of $L$. infantum MON-1 in Morocco as in the remaining Mediterranean Basin (Dereure et al., 1986).

The three species of Larroussius sandflies that have been incriminated elsewhere in the transmission of visceral leishmaniasis (Killick-Kendrick, 1990), i. e. P. ariasi (Rioux et al., 1984), P. perniciosus (Rioux et al., 1986a) and P. longicuspis (Parrot et al., 1952 in Killick-Kendrick, 1990) are present in Ouled Hcein locality (Table II). Furthermore and for the first time in Morocco, the identification of one female of $P$. ariasi naturally infected with $L$. infantum at the end of the season inside the house of the index child led to highly suspect this species as a vector of this parasite in this area. However, one must keep in mind that more than one species of Larroussius subgenus may transmit the parasite in the same place (Killick-Kendrick, 1990). Furthermore the sandflies collected in this survey are mostly endophilic. The concomitant existence of a high canine leishmaniasis seroprevalence and the high rate of $P$. longicuspis previously demonstrated as a vector of canine $L$. infantum in Algeria (Parrot et al., 1952, in Killick-Kendrick, 1990) could highlight the zoonotic character of Ouled Hcein focus and indicates that this locality and maybe the province in general is at risk of transmission of visceral leishmaniasis so that this region should be surveyed more closely. According to the seasonality of the Larroussius subgenus, September seems to be the probable transmission period. Moreover, besides human visceral leishmaniasis seven cases of cutaneous leishmaniasis were reported to the national health authorities between 1991 and 1995 (unpublished data). Even if no cutaneous strain could be up to now isolated and typed, it can be assumed that either L. major or L. tropica could be the etiologic agents according to the entomological data here reported showing the existence of specific demonstrated vectors, respectively $P$. papatasi (Rioux et al., 1986b) and P. sergenti (Rioux et al., 1986a); cutaneous leishmaniasis due to L. infantum is not as yet reported in Morocco.

\section{CONCLUSION}

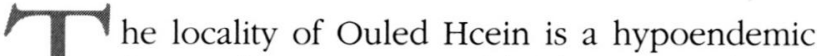
focus of human visceral leishmaniasis due to L. infantum MON-1. The relative high seropositivity rate indicates an active focus of canine leish- maniasis which puts this locality at risk of human visceral disease. Finally, at least one of the vectors of $L$. infantum is P. ariasi. The survey is still going on to confirm these results and finalize the transmission cycle of the parasite in this area.

\section{AKNOWLEDGEMENTS}

${ }_{\text {his work was supported by the Agency for }}$ International Development and the National Institute of Health, USA, through the MERC program (Contract NO1-AO-45185).

We are grateful to Profs. C. Jaffe and L. Schnur from the Hadassah Medical School, Jerusalem, Israel, who respectively kindly provided for the Leishmania characterization the monoclonal antibodies and excreted factors antibodies and reference antigens.

We are grateful to Dr. P. Melby (University of Texas, Health Science Center, Department of Medicine, Division of Infectious Diseases, San Antonio, USA) for his comments.

We are grateful to the Moroccan Ministry of Health (Drs. Mahjour and Laamrani-Idrissi) and the local authorities of the province of Taounate (Dr. Alaoui Belghiti, MD delegate) for their logistical support.

\section{REFERENCES}

Brandonisio O., Carelli G., Ceci L., Consenti B., Fasanella A. \& Puccini V. Canine leishmaniasis in the Gargano promontory (Apulia, South Italy). European Journal of Epidemiology, 1992, 8(2), 273-276

DEDET J.P. Épidémiologie mondiale de la leishmaniose viscérale. Médecine et Maladies Infectieuses, 1994a, 24, $562-$ 565.

Dedet J.P. Leishmanioses dans le monde. Médecine et Armées, $1994 b, 22,7-10$.

Dereure J., Rioux J.A., Khiami A., Pratlong F., Perieres J. \& Martini A. Écoépidémiologie des leishmanioses en Syrie. 2. Présence chez le chien de Leishmania infantum Nicolle et Leishmania tropica Wright (Kinetoplastidae-Trypanosomatidae). Annales de Parasitologie Humaine et Comparée, 1991, 66, 252-255.

Dereure J., Velez I.D., Pratlong F., Denial M., Lardi M., Moreno G., Serres E., Lanotte G. \& Rioux J.A. La leishmaniose viscérale autochtone au Maroc méridional. Présence de Leishmania infantum MON-1 chez le Chien en zone présaharienne, in: Leishmania. Taxonomie et Phylogenèse. Applications éco-épidémiologiques, IMEEE (éd.), Montpellier, 1986, 421-425.

Guilvard E., Rioux J.A., Gallego M., Pratlong F., Mahjour J., Martinez-Ortega E., Sadiki A. \& Martini A. L. tropica au Maroc. III. Rôle vecteur de P. sergenti. À propos de 89 isolats. Annales de Parasitologie Humaine et Comparée, 1991, 66, 96-99 
KILlick-KendricK R. Phlebotomine vectors of the leishmaniases: a review. Medical and Veterinary Entomology, 1990, 4, 1-24.

Martin Sanchez J., Morrillas Marquez F., Sanchiz Marin M. \& ACEDo SANCHEZ C. Isoenzymatic characterization of the aetiologic agent of canine leishmaniasis in the Granada region of Southern Spain. American Journal of Tropical Medicine and Hygiene, 1994, 50, 758-762.

Marty P., Le Fichoux Y., Giordana D. \& Brugnetti A. Leishmanin reaction in the human population of a highly endemic focus of canine leishmaniasis in Alpes-Maritimes, France. Transactions of the Royal Society of Tropical Medicine and Hygiene, 1992, 86(3), 249-250.

Ministère de la SANTÉ Publique du Maroc, Direction de l'Épidémiologie et des Programmes Sanitaires. Bulletin Épidémiologique, 1992, 7, 1-20.

Rioux J.A., JaRry D.M., LANOTTE G., MaAzoun R. \& Killick-KenDRICK R. Écologie des leishmanioses dans le sud de la France. 18. Identification enzymatique de Leishmania infantum Nicole, 1908, isolé de Pblebotomus ariasi, Tonnoir, 1921, spontanément infesté en Cévennes. Annales de Parasitologie Humaine et Comparée, 1984, 59, 331-333.

Rioux J.A., Guilvard E., Gallego J., Moreno G., Pratlong F., Portus M., Rispail P., Gallego M. \& Bastien P. Phlebotomus ariasi Tonnoir, 1921, et Phlebotomus perniciosus Newstead, 1911, vecteur du complexe Leishmania infantum dans un même foyer, in: Leishmania. Taxonomie et Phylogenèse. Applications éco-épidémiologiques, IMEEE (éd.), Montpellier, 1986a, 439-444.

Rioux J.A., Lanotte G., Petter F., Dereure J., Akalay O., Pratlong F., Velez I.D., Fikri N.B., Maazoun R., Denial M., Jarky D.M., Zahaf A., Ashford R.W., CADI-Soussi M., KillicKKendrick R., Benmansour R., Moreno G., Perieres J., Guilvard E., Zribi M., Kennou M.F., Rispail P., Knechtli R. \& Serres E. Les leishmanioses cutanées du bassin méditerranéen occidental. De l'identification enzymatique à l'analyse éco-épidémiologique. L'exemple de trois "foyers ", tunisien, marocain et français, in: Leishmania. Taxonomie et Phylogenèse. Applications éco-épidémiologiques, IMEEE (éd.), Montpellier, 1986b, 365-395.

Reçu le 19 août 1996 Accepté le 14 mars 1997 